Nepal Agric. Res. J. Vol. 9, 2009

\title{
Study on the Effects of Vermicompost on the Nodulation and the Yield of Chickpea
}

\author{
Sanu K. Bajracharya and Suresh K. Rai \\ Soil Science Division, NARC, Khumaltar, Lalitapur, Nepal \\ <sk_bajracharya@hotmail.com>
}

\begin{abstract}
Pot experiment was conducted in a randomized complete block design with three replication and six treatments in the screenhouse of Soil Science Division, Khumaltar during the year 2003 and 2004. The objective of the experiment was to find out the effect of vermicompost in combination with or without soil and mineral fertilizers on the yield and other attributes of chickpea. The results showed an encouraging effect of vermicompost application on the plant height, root length and biomass dry weight of chickpea when vermicompost was applied in equal ratio with soil $(5 \mathrm{~kg}$ each/pot) and 10:20:15 kg N: $\mathrm{P}_{2} \mathrm{O}_{5}: \mathrm{K}_{2} \mathrm{O} \mathrm{kg} \mathrm{ha}{ }^{-1}$. Vermicompost with equal ratio of soil $(5 \mathrm{~kg}$ each/pot) also produced the highest mean grain yield of $10.6 \mathrm{gm}$ per pot. However, no significant treatments effects were observed for root length and straw weights of the chickpea.
\end{abstract}

Kew words: Chickpea, mineral fertilizer, nodulation, vermicompost, yield

\section{INTRODUCTION}

Legumes are mostly grown in Nepal as a source of human and animal protein. It enriches the soil with nitrogen maintaining soil fertility by fixing atmospheric nitrogen with the help of rhizobium associated in the root nodules. In Nepal, the common legumes grown in terai during winter are lentil, mungbean, chickpea, cowpea, pigeon pea and horse gram, while in hill and valley, soybean, phaseolus bean and black gram are grown during summer (MoAC 1999). In the recent years, the area under legumes cultivation is decreasing due to many biotic and abiotic factors (Neupane et al 2005). Among the biotic factors; fewer number of nodules in the root system, pest infection are few examples while drought, soil acidity and unfavorable soil conditions comprise the abiotic factors. In addition, soil health and the proper nutrient management are also important factors that may limit the legume production.

Except on vermicompost, several research works on bacterial, mineral and organic fertilizers from various sources have already been done in Nepal (Maskey and Bhattarai 1994). Compost produced by traditional processes is generally low in plant nutrient content and the process itself is also slow and time consuming. On the other hand, certain special type of earthworm (Eisenia foitida) has the capacity to convert the biodegradable organic waste into higher quality compost at comparatively faster rate (Bhattarai 2003) than that of the traditional method. Such a compost usually known as "vermicompost" is rich in plant nutrients and contains higher number of microorganisms, which are 
responsible for decomposition process (Yami et al 2003). Hence, in order to find out the effect of vermicompost either alone and/or in combination with soil and mineral fertilizers on the yield and other parameters of chickpea, this experiment was conducted.

\section{MATERIALS AND METHODS}

The experiment was conducted in a randomized complete block design with six treatments and three replications, each treatment conducted on an earthen pot of $12 \mathrm{~kg}$ capacity filled with vermicompost alone and/or mixed with soil and/or mineral fertilizers up to $10 \mathrm{~kg}$ capacity depending upon the type of treatment. The experiment was laid out in the screen house of Soil Science Division, Khumaltar, Lalitpur during year 2003 and 2004. The vermicompost with $1.4 \% \mathrm{~N}, 0.8 \% \mathrm{P}$ and $4.38 \% \mathrm{~K}$ content was used in the experiment, which was prepared from the farm waste. The nutrient content of the soil used in the pot were $\mathrm{N} \% 0.156, \mathrm{P}_{2} \mathrm{O}_{5} 155 \mathrm{~kg} \mathrm{ha}^{-1}, \mathrm{~K}_{2} \mathrm{O} 874 \mathrm{~kg} \mathrm{ha}^{-1}$ and $\mathrm{OM} \% 2.01$ with soil $\mathrm{pH}$ of 5.6. In each of the pot, seven seeds of local chickpea cultivar were sown. One week after germination, plants were thinned to five plants in each pot. Urea, single super phosphate (SSP) and muriate of potash (MOP) were applied in liquid form in single application at one week after germination. The cultural practices were followed as normal as and when required. At the $50 \%$ maturity stage, single plant was taken out from every pot for recording nodulation, plant height, root length and dry biomass. After 90 days of seeding, crop was harvested and grain and straw yield were recorded. Statistical analysis of the data was done in MSTAT-C version 2.1 software. The treatment details are given below:

\begin{tabular}{ll}
\hline Treatments & Details \\
\hline Treatment 1 & Control (Soil 10 kg/pot) \\
Treatment 2 & Soil + Vermicompost $(5 \mathrm{~kg}$ each/pot $)$ \\
Treatment 3 & Vermicompost $(10 \mathrm{~kg} /$ pot) \\
Treatment 4 & Soil $(10 \mathrm{~kg} /$ pot $)+$ Full dose of mineral fertilizer $\left(20: 40: 30 \mathrm{~N}: \mathrm{P}_{2} \mathrm{O}_{5}: \mathrm{K}_{2} \mathrm{O}\right.$ \\
& $\mathrm{kg} / \mathrm{ha})$ \\
Treatment 5 & Soil $(5 \mathrm{~kg} / \mathrm{pot})+$ Vermicompost $(5 \mathrm{~kg} /$ pot $)+$ Half dose of mineral \\
& fertilizer $\left(10: 20: 15 \mathrm{~N}: \mathrm{P}_{2} \mathrm{O}_{5}: \mathrm{K}_{2} \mathrm{O} \mathrm{kg} /\right.$ ha $)$ \\
Treatment 6 & Soil $(10 \mathrm{~kg} /$ pot $)+$ high dose of mineral fertilizer $\left(60: 60: 60 \mathrm{~N}: \mathrm{P}_{2} \mathrm{O}_{5}: \mathrm{K}_{2} \mathrm{O}\right.$ \\
& $\mathrm{kg} / \mathrm{ha})$ \\
\hline
\end{tabular}

\section{RESULTS AND DISCUSSION}

Plant height

Effect of the treatments on plant height was highly significant in the first year but was insignificant in the second year of the experiment (Table 1). The highest plant height $(46.2 \mathrm{~cm})$ was obtained from treatment 5 having equal amount of soil and vermicompost $(5 \mathrm{~kg}$ each $/$ pot $)$ plus half dose of recommended mineral fertilizer $\left(10: 20: 15 \mathrm{~N}: \mathrm{P}_{2} \mathrm{O}_{5}: \mathrm{K}_{2} \mathrm{O} \mathrm{kg} / \mathrm{ha}\right)$ followed by treatment $3(40.7 \mathrm{~cm})$ having only vermicompost @ $10 \mathrm{~kg} /$ pot. In the second year, treatment effects were insignificant however, treatment 6 (Soil $10 \mathrm{~kg} / \mathrm{pot}+$ high dose of mineral fertilizer @ 60:60:60 N: $\mathrm{P}_{2} \mathrm{O}_{5}: \mathrm{K}_{2} \mathrm{O}$ $\mathrm{kg} / \mathrm{ha}$ ) produced the highest plant height of $46.2 \mathrm{~cm}$ followed by treatment $2(45.0 \mathrm{~cm})$. In the combined analysis of the two years data, treatment 2 having equal amount of soil and vermicompost produced the significantly highest plant height of $42.6 \mathrm{~cm}$ followed by treatment $5(42.0 \mathrm{~cm})$ and treatment $3(41.5 \mathrm{~cm})$ respectively. Interaction between treatment and year was highly significant $(\mathrm{p}$ $=0.0017)$. Treatment effects was also significant $(\mathrm{p}=0.0342)$. Increased in plant height is possibly due to the growth promoting substances, which are present in vermicompost. Nutrients from soil and 
fertilizers have also their effects on the plant heights. Similar results have also been reported by Asewar et al (2004) and Arya et al (2007).

\section{Root length}

In the both the years of the experiment, treatment effects were not observed significant for root length (Table 1). However, the effect of vermicompost alone and with other combination was quite impressive. In the first year, treatment 5 produced the highest root length $(14.6 \mathrm{~cm})$ while treatment 2 produced the highest root length of $15.5 \mathrm{~cm}$ in the second year. An insignificant response was observed when combined analysis was done.

\section{Nodulation}

The effects of the treatments on the count of the nodulation were quite noticeable in both of the years (Table 2). Unexceptionally, the number of nodulation in the second year was higher than the first year due to more rhizobial activity in the second year. Both treatment effects and their interaction over years were highly significant (Table 2). In the first year, treatment 3 (vermicompost only) produced the highest number of nodules per plant (16) followed by treatment 2 (14) which was comprised of equal amount of soil and vermicompost. This could be possibly due to the different type of enzymes produced by organic fertilizers (vermicompost) that helped to produce increased number of nodules in the plants.

Table 1. Treatment effects on plant height and root length of chickpea (2003-2004)

\begin{tabular}{|c|c|c|c|c|c|c|c|}
\hline & \multirow[b]{2}{*}{ Treatment details } & \multicolumn{3}{|c|}{ Plant height/plant, $\mathrm{cm}$} & \multicolumn{3}{|c|}{ Root length/plant, cm } \\
\hline & & 2003 & 2004 & Mean & 2003 & 2004 & Mean \\
\hline 1 & Control (Soil $10 \mathrm{~kg} / \mathrm{pot}$ ) & $23.7^{\mathrm{c}}$ & 43.5 & $33.6^{b}$ & 11.2 & 15.7 & 13.5 \\
\hline 2 & $\begin{array}{l}\text { Soil + Vermicompost }(5 \mathrm{~kg} \\
\text { each/pot) }\end{array}$ & $40.2^{\mathrm{ab}}$ & 45.0 & $42.6^{\mathrm{a}}$ & 13.7 & 15.5 & 14.6 \\
\hline 3 & $\begin{array}{l}\text { Vermicompost }(10 \mathrm{~kg} / \mathrm{pot}) \\
\text { Soil }(10 \mathrm{~kg} / \mathrm{pot})+\text { Full dose }\end{array}$ & $40.7^{\mathrm{ab}}$ & 42.2 & $41.5^{\mathrm{a}}$ & 12.5 & 12.7 & 12.6 \\
\hline 4 & $\begin{array}{l}\text { of mineral fertilizer } \\
\left(20: 40: 30 \mathrm{~N}: \mathrm{P}_{2} \mathrm{O}_{5}: \mathrm{K}_{2} \mathrm{O}\right. \\
\mathrm{kg} / \mathrm{ha})\end{array}$ & $30.1^{\mathrm{bc}}$ & 43.5 & $36.8^{\mathrm{ab}}$ & 12.0 & 15.2 & 13.6 \\
\hline & $\begin{array}{l}\text { Soil (5 } \\
\mathrm{kg} / \text { pot)+Vermicompost }\end{array}$ & & & & & & \\
\hline 5 & $\begin{array}{l}(5 \mathrm{~kg} / \text { pot })+\text { Half dose of } \\
\text { mineral fertilizer }(10: 20: 15 \\
\left.\mathrm{N}: \mathrm{P}_{2} \mathrm{O}_{5}: \mathrm{K}_{2} \mathrm{O} \mathrm{kg} / \mathrm{ha}\right)\end{array}$ & $46.2^{\mathrm{a}}$ & 37.7 & $42.0^{\mathrm{a}}$ & 14.6 & 14.0 & 14.3 \\
\hline 6 & $\begin{array}{l}\text { Soil }(10 \mathrm{~kg} / \mathrm{pot})+\text { high dose } \\
\text { of mineral fertilizer } \\
\left(60: 60: 60 \mathrm{~N}: \mathrm{P}_{2} \mathrm{O}_{5}: \mathrm{K}_{2} \mathrm{O}\right. \\
\mathrm{kg} / \mathrm{ha})\end{array}$ & $37.1^{\mathrm{ab}}$ & 46.2 & $41.6^{\mathrm{a}}$ & 14.3 & 10.7 & 12.5 \\
\hline & Mean & 36.37 & 43.04 & 39.70 & 13.083 & 14.00 & 13.57 \\
\hline & $\mathrm{CV}, \%$ & 19.34 & 11.88 & 15.49 & 28.220 & 23.88 & 26.01 \\
\hline & F-test & & & & & & \\
\hline & Treatment & $* *$ & $\mathrm{~ns}$ & $*$ & $\mathrm{~ns}$ & ns & $\mathrm{ns}$ \\
\hline & Year $\times$ Treatment & - & - & $* *$ & - & - & ns \\
\hline & LSD & 10.37 & & 6.281 & & & \\
\hline
\end{tabular}

ns, not significant. *, significant (0.05). **, highly significant (0.01). 


\section{Biomass dry weight}

Biomass production was not significantly different in the second year as compared to the first year (Table 2). In the first year of the experiment, the treatment 5 (equal amount of soil and vermicompost plus half of the recommended mineral fertilizers) out yielded other by producing 2.84 gm per plant biomass. Vermicompost alone (treatment 5) produced the second highest biomass production of $2.23 \mathrm{gm}$ per plant. In the second year, the effects of the treatments were insignificant. This could be due to the increased microbial activities produced by the organic fertilizers, which might have been developed at the end of the second year. Similar result was also reported by Rajkhowa et al (2000). Variation due to years and treatments on combined analysis showed a significant response on biomass dry weight production.

Table 2. Treatment effect on nodulation and biomass dry weight of chickpea (20032004)

\begin{tabular}{|c|c|c|c|c|c|c|c|}
\hline & \multirow{2}{*}{ Treatment details } & \multicolumn{3}{|c|}{ No. of nodules/plant } & \multicolumn{3}{|c|}{$\begin{array}{c}\text { Biomass dry } \\
\text { weight/plant, } g\end{array}$} \\
\hline & & 2003 & 2004 & Mean & 2003 & 2004 & Mean \\
\hline 1 & Control (Soil 10 kg/pot) & $8.0^{\mathrm{bc}}$ & $71.2^{\mathrm{ab}}$ & $39.6^{\mathrm{a}}$ & $0.30^{\mathrm{d}}$ & 2.7 & 1.5 \\
\hline 2 & $\begin{array}{l}\text { Soil + Vermicompost (5 kg } \\
\text { each/pot) }\end{array}$ & $14.0^{\mathrm{ab}}$ & $64.5^{\mathrm{ab}}$ & $39.2^{\mathrm{a}}$ & $2.23^{\mathrm{ab}}$ & 2.9 & 2.5 \\
\hline 3 & $\begin{array}{l}\text { Vermicompost }(10 \mathrm{~kg} / \text { pot }) \\
\text { Soil }(10 \mathrm{~kg} / \text { pot })+\text { Full dose }\end{array}$ & $16.0^{\mathrm{a}}$ & $6.0^{\mathrm{d}}$ & $11.0^{\mathrm{b}}$ & $1.77^{\mathrm{abc}}$ & 2.4 & 2.1 \\
\hline 4 & $\begin{array}{l}\text { of mineral fertilizer } \\
\left(20: 40: 30 \mathrm{~N}: \mathrm{P}_{2} \mathrm{O}_{5}: \mathrm{K}_{2} \mathrm{O}\right. \\
\mathrm{kg} / \mathrm{ha})\end{array}$ & $5.0^{\mathrm{cd}}$ & $46.7^{\mathrm{bc}}$ & $25.8^{\mathrm{ab}}$ & $0.54^{\mathrm{cd}}$ & 2.9 & 1.7 \\
\hline & $\begin{array}{l}\text { Soil } \\
\text { (5kg/pot)+Vermicompost }\end{array}$ & & & & & & \\
\hline 5 & $\begin{array}{l}(5 \mathrm{~kg} / \text { pot })+\text { Half dose of } \\
\text { mineral fertilizer }(10: 20: 15 \\
\left.\mathrm{N}: \mathrm{P}_{2} \mathrm{O}_{5}: \mathrm{K}_{2} \mathrm{O} \mathrm{kg} / \mathrm{ha}\right)\end{array}$ & $3.0^{\mathrm{cd}}$ & $11.0^{\mathrm{cd}}$ & $7.0^{\mathrm{b}}$ & $2.84^{\mathrm{a}}$ & 2.5 & 2.7 \\
\hline 6 & $\begin{array}{l}\text { Soil }(10 \mathrm{~kg} / \mathrm{pot})+\text { high dose } \\
\text { of mineral fertilizer } \\
\left(60: 60: 60 \mathrm{~N}: \mathrm{P}_{2} \mathrm{O}_{5}: \mathrm{K}_{2} \mathrm{O}\right)\end{array}$ & $1.0^{\mathrm{d}}$ & $90.2^{\mathrm{a}}$ & $45.6^{\mathrm{a}}$ & $0.88^{\mathrm{bcd}}$ & 3.1 & 1.9 \\
\hline & Mean & 7.833 & 48.29 & 28.06 & 1.429 & 2.79 & 2.107 \\
\hline & $\mathrm{CV}, \%$ & 74.15 & 51.52 & 64.3 & 65.11 & 36.14 & 46.0 \\
\hline & F-test & & & & & & \\
\hline & Treatment & $*$ & $* *$ & $* *$ & $* *$ & ns & ns \\
\hline & Year $\times$ Treatment & - & - & $* *$ & - & - & * \\
\hline & LSD & 6.19 & 36.66 & 24.84 & 1.370 & & 2.329 \\
\hline
\end{tabular}

ns, not significant. *, significant (0.05). **, highly significant (0.01).

\section{Grain and straw yields}

The effects of the treatments were significant on grain yield of chickpea in both the years (Table 3 ). In the first year, treatment 2 (equal amount of soil and vermicompost) produced the highest mean grain yield of 14.2 gm per plot followed by treatment 5 (equal amount of soil and vermicompost plus half of the recommended mineral fertilizers) with the mean grain yield of 14.03 gm per plant. In 
the second year, treatment 6 out yielded others by producing the highest mean grain yield of $7.3 \mathrm{gm}$ per plot followed by treatment 2 with the mean grain yield of $6.9 \mathrm{gm}$ per plot. Similar effects on the grain yield have been reported by Rajkhowa et al (2000), when vermicompost was applied with mineral fertilizers. Bhattarai (2003) has also reported the increase in the grain yield of wheat and maize when soil and vermicompost was applied at equal ratio (1:1).

Table 3. Treatment effect on grain and straw yield of chickpea (2003-2004)

\begin{tabular}{|c|c|c|c|c|c|c|c|}
\hline \multirow{2}{*}{\multicolumn{2}{|c|}{ Treatment details }} & \multicolumn{3}{|c|}{ Grain yield, $g$} & \multicolumn{3}{|c|}{ Straw yield/pot, $g$} \\
\hline & & \multirow{2}{*}{$\frac{2003}{5.4^{\mathrm{c}}}$} & \multirow{2}{*}{$\begin{array}{r}2004 \\
6.3^{\mathrm{a}}\end{array}$} & \multirow{2}{*}{$\begin{array}{r}\text { Mean } \\
5.8\end{array}$} & \multirow{2}{*}{$\begin{array}{r}2003 \\
8.4\end{array}$} & \multirow{2}{*}{$\begin{array}{l}2004 \\
41.07\end{array}$} & \multirow{2}{*}{$\frac{\text { Mean }}{24.7^{\mathrm{a}}}$} \\
\hline 1 & Control (soil $10 \mathrm{~kg} / \mathrm{pot}$ ) & & & & & & \\
\hline 2 & $\begin{array}{l}\text { Soil + Vermicompost ( } 5 \mathrm{~kg} \\
\text { each/pot) }\end{array}$ & $14.2^{\mathrm{a}}$ & $6.9^{\mathrm{a}}$ & 10.6 & 19.2 & 59.3 & $39.3^{\mathrm{ab}}$ \\
\hline 3 & Vermicompost (10 kg/pot) & $11.6^{\mathrm{ab}}$ & $2.9^{\mathrm{b}}$ & 7.3 & 17.6 & 77.9 & $47.8^{\mathrm{a}}$ \\
\hline 4 & $\begin{array}{l}\text { Soil }(10 \mathrm{~kg} / \text { pot })+\text { Full dose of } \\
\text { mineral fertilizer }(20: 40: 30 \mathrm{~N} \text { : } \\
\left.\mathrm{P}_{2} \mathrm{O}_{5}: \mathrm{K}_{2} \mathrm{O} \mathrm{kg} / \mathrm{ha}\right)\end{array}$ & $7.6^{\mathrm{bc}}$ & $6.3^{\mathrm{a}}$ & 7.0 & 10.6 & 67.4 & $39.06^{\mathrm{ab}}$ \\
\hline 5 & $\begin{array}{l}\text { Soil }(5 \mathrm{~kg} / \text { pot })+\text { Vermicompost } \\
(5 \mathrm{~kg} / \text { pot })+\text { Half dose of } \\
\text { mineral fertilizer }(10: 20: 15 \mathrm{~N} \text { : } \\
\left.\mathrm{P}_{2} \mathrm{O}_{5}: \mathrm{K}_{2} \mathrm{O} \mathrm{kg} / \mathrm{ha}\right)\end{array}$ & $14.03^{\mathrm{a}}$ & $3.5^{\mathrm{b}}$ & 8.7 & 13.7 & 56.1 & $34.9^{\mathrm{ab}}$ \\
\hline 6 & $\begin{array}{l}\text { Soil }(10 \mathrm{~kg} / \text { pot })+\text { High dose of } \\
\text { mineral fertilizer }(60: 60: 60 \mathrm{~N} \text { : } \\
\left.\mathrm{P}_{2} \mathrm{O}_{5}: \mathrm{K}_{2} \mathrm{O} \mathrm{kg} / \mathrm{ha}\right)\end{array}$ & $10.02^{\mathrm{ab}}$ & $7.3^{\mathrm{a}}$ & 8.6 & 14.1 & 62.0 & $38.0^{\mathrm{ab}}$ \\
\hline & Mean & 10.50 & 5.573 & 8.038 & 13.98 & 60.68 & 37.32 \\
\hline & $\mathrm{CV}, \%$ & 36.23 & 38.88 & 38.52 & 72.32 & 26.05 & 35.55 \\
\hline & F-test & & & & & & \\
\hline & Treatment & $*$ & $*$ & ns & ns & ns & $*$ \\
\hline & Year $\times$ Treatment & - & - & $* *$ & - & - & ns \\
\hline & LSD & 4.055 & 2.309 & & & & 13.55 \\
\hline
\end{tabular}

ns, not significant. *, significant (0.05). **, highly significant (0.01).

Treatment response to straw yields over the two years were not significant (Table 3). However, it was found significant when combined analysis over two years was performed. In the first year, treatment 2 produced the highest mean straw $(19.2 \mathrm{~g} / \mathrm{pot})$ and treatment 3 was the highest with 77.9 gm per pot in the second year. Treatment 3 also produced the significant highest mean yield of 47.8 gm per pot followed by treatment 2 (39.3 gm per pot) when combined analysis was performed on straw yield. Straw yield was more or less similar in treatment 2, 4 and 6 indicating that application of vermicompost alone or in combination with equal amount of soil and half dose of mineral fertilizer is better for straw yield. Similar result has also been reported by Bajracharya et al (2007). Jat and Ahlawat (2004) also observed significantly increased in straw yield with the application of vermicompost only.

\section{Correlation of the plant parameters}

Correlation analysis of biomass dry weight, nodule numbers, plant height, root length, grain yield and straw yield has been presented in the table 4 . A high degree of significant association of biomass dry weight was observed with nodule numbers, plant height and straw yield. A very high degree of positive association was observed between plant height and biomass dry weight (0.754). Similarly, straw yield and nodule number have also positive correlation with biomass dry weight. A negative insignificant relation was obtained between grain yield and nodulation number (-0.1294). 
Table 4. Correlation analysis of the plant parameters (Correlation/P-Value)

\begin{tabular}{lccccr}
\hline & $\begin{array}{c}\text { Biomass } \\
\text { dry weight }\end{array}$ & $\begin{array}{r}\text { Nodules } \\
\text { number }\end{array}$ & Plant height & Root length & $\begin{array}{r}\text { Grain } \\
\text { yield }\end{array}$ \\
\hline Nodules & 0.4660 & & & & \\
number & 0.0008 & & & & \\
Plant height & 0.7544 & 0.3138 & & & \\
& 0.0000 & 0.0298 & & & \\
Root length & 0.3187 & 0.1082 & 0.2077 & & \\
& 0.0272 & 0.4643 & 0.1565 & & \\
Grain yield & -0.0651 & -0.1294 & 0.1242 & -0.0378 & \\
& 0.6602 & 0.381 & 0.4002 & 0.7986 & \\
Straw yield & 0.4682 & 0.3775 & 0.374 & 0.0930 & -0.3722 \\
& 0.0008 & 0.0082 & 0.0089 & 0.5293 & 0.0092 \\
\hline
\end{tabular}

\section{CONCLUSION}

The effect of vermicompost in combination with other mineral fertilizer and/or soil is quite encouraging for better crop growth and yield of chickpea. Even at the lower dose than that of the recommended dose of the mineral fertilizers, vermicompost has shown better results for nodulation and crop yield, which is not only economical but also beneficial with soil improvement point of view.

\section{ACKNOWLEDGEMENTS}

Authors are grateful to Dr SL Maskey, Chief, Soil Science Division for providing facilities to carry out the experiment and for the valuable suggestion during the research period. Mr Sambhu Raut and Mr Shri Krishna $\mathrm{KC}$ are highly acknowledged for their technical assistance in the research work. All the other staffs involved in the experiment are also acknowledged for their support.

\section{REFERENCES}

Arya RL, JG Varshney, L Kumar. 2007. Effect of integrated nutrient application in chickpea mustard intercropping system in the semi-arid tropics of North India. Communications in Soil Science and Plant Analysis 38(1\&2):229-240.

Asewar BV, SS Bainade, OD Kohire and PS Bainade. 2004. Integrated use of vermicompost and inorganic fertilizer in chickpea. Indian Journal of Agriculture 7:359361.

Bajracharya SK, DP Sherchan and S Bhattarai. 2007. Effect of vermicompost in combination with bacterial and mineral fertilizers on the yield of vegetable soybean. Korean J. Crop Science 52(1):100-103. 
Bhattarai S. 2003. Quality compost production with vermicompost from the farm and household waste. In: Proceedings international conference on woman, science and technology for poverty alleviation, 31 March to 2 April 2003, Katmandu, Nepal.

Jat RS and IPS Ahlat. 2004. Effect of vermicompost, biofertilizer and phosphorus on growth and nutrient uptake by gram (Cicer arietinum) and their residual effect on fodder maize (Zea mays). Indian Journal of Agricultural Science 74(7):359-361.

Maskey SL and S Bhattarai. 1994. Effect of long term application on different sources of organic manure on maize/wheat rotation. In: Proceeding of IInd National conference on science and technology, 8-11 June 1994, RONAST, Kathmandu. Pp. 215-217.

MoAC. 1999. Statistical information of Nepalese agriculture 1993/94. Agricultural Statistics Division, Ministry of Agriculture and Cooperative (MoAC), Kathmandu, Nepal.

Neupane RK, M Joshi, S Pande and NK Yadav. 2005. On-farm IPM of chickpea in Nepal: Dissemination, adoption and promotion, summary of NARC-ICRISAT-NRI workshop, November 2004, Katmandu, Nepal. Pp. 17-18.

Rajkhowa DJ, AK Gogoi, R Kandali and KM Rajkhowa. 2000.Effect of vermicompost on green gram nutrition. Journal of the Indian Society of Soil Science 48(1):207-208.

Yami KD, S Bhattarai and S Adhikari. 2003. Vermicomposting and microflora analysis of vermicompost and gut of red earthworm. Nepal Journal of Science and Technology $5: 127-132$. 